\title{
Preparation and Evaluation of Chitosan Beads Immobilized with Iron(III) for the Removal of As(III) and As(V) from Water
}

\author{
José de O. Marques Neto, Carlos R. Bellato, * Jaderson L. Milagres, \\ Kenia D. Pessoa and Elson S. de Alvarenga
}

Department of Chemistry, Federal University of Viçosa, 36570-000 Viçosa-MG, Brazil

\begin{abstract}
$\mathrm{O}$ adsorvente quitosana-Fe(III)-reticulado (Ch-FeCL) foi desenvolvido usando $\mathrm{Fe}(\mathrm{III})$ imobilizado em esferas de quitosana. Após o processo de secagem, as esferas apresentam um diâmetro de cerca de 1 mm e são estáveis ao ar. O comportamento de adsorção do As(III) e As(V) na $\mathrm{Ch}-\mathrm{FeCL}$ foi avaliado em $\mathrm{pH} 7$ por estudos realizados em batelada e em coluna. As máximas capacidades de adsorção estimadas pelo modelo de adsorção de Langmuir foram 21,24 e 27,59 mg $\mathrm{g}^{-1}$ para $\mathrm{As}(\mathrm{III})$ e $\mathrm{As}(\mathrm{V})$, respectivamente. A cinética de adsorção é descrita pela equação cinética de pseudo-segunda ordem. Os resultados de adsorção em coluna indicaram que o arsênio não foi encontrado na solução efluente até cerca de 60 e 759 volumes de leito para As(III) e As(V), respectivamente. Os resultados foram satisfatórios quando se empregou o adsorvente na remoção de $\mathrm{As}(\mathrm{III})$ e As(V) de amostras de águas subterrâneas, torneira e rio.
\end{abstract}

The crosslinked chitosan-Fe(III) (Ch-FeCL) adsorbent was developed using Fe(III) immobilized on chitosan beads. After drying, the beads presented a diameter of approximately $1 \mathrm{~mm}$ and are stable in air. The adsorption behavior of $\mathrm{As}(\mathrm{III})$ and $\mathrm{As}(\mathrm{V})$ on the $\mathrm{Ch}-\mathrm{FeCL}$ was evaluated at $\mathrm{pH} 7$ by studies conducted in batch and in columns. Maximum adsorption capacities estimated by the Langmuir adsorption model were 21.24 and $27.59 \mathrm{mg} \mathrm{g}^{-1}$ for As(III) and As(V), respectively. Adsorption kinetics is described by the pseudo second order kinetic equation. The results of column adsorption indicated that arsenic was not found in the effluent solution from roughly 60 and 759 bed volumes for As(III) and As(V), respectively. Results were satisfactory when employing the adsorbent for removal of $\mathrm{As}(\mathrm{III})$ and $\mathrm{As}(\mathrm{V})$ from groundwater, tap water and river water samples.

Keywords: iron-chitosan, arsenic, removal, adsorption isotherm, groundwater

\section{Introduction}

Arsenic is a highly toxic element mainly present in drinking water and seafood, and its contamination may cause dermatitis, skin cancer, neurological disorders, hepatomegaly, heart problems, internal cancers and poisoning. ${ }^{1}$ Arsenic can be encountered in high concentrations in surface and ground waters as a consequence of natural wear of arsenic-bearing minerals (especially arsenopyrite), as well as by human activities that promote its availability in the soil. ${ }^{2}$ Arsenic is found in water in several different forms depending on $\mathrm{pH}$ and redox potential $\left(\mathrm{E}_{\mathrm{h}}\right)$ of the medium, where the inorganic species, arsenite and arsenate are more toxic than the organic species. Arsenate $(\mathrm{As}(\mathrm{V}))$ and arsenite (As(III)) are the primary forms of arsenic found in natural waters, being that $\mathrm{As}(\mathrm{V})$ is more thermodynamically

*e-mail: bellato@ufv.br stable in oxygenated surface waters and As(III) in groundwater. ${ }^{3}$ These species exist as oxyanions, in which the dominant arsenite species is the neutral species $\mathrm{H}_{3} \mathrm{AsO}_{3}$ $\left(\mathrm{pK}_{1}=9.22\right)$ and the dominant arsenates are the negative species $\mathrm{HAsO}_{4}{ }^{2-}\left(\mathrm{pK}_{1}=2.20\right)$ and $\mathrm{H}_{2} \mathrm{AsO}_{4}^{-}\left(\mathrm{pK}_{2}=6.97\right)$ when the $\mathrm{pH}$ is within an intermediate range between 3 and 9. Arsenic(V) is indicated as the predominant specie in conditions of extreme acidity and alkalinity, $\mathrm{H}_{3} \mathrm{AsO}_{4}$ and $\mathrm{AsO}_{4}{ }^{3-}$, respectively. ${ }^{3,4}$ Arsenic compounds present different toxicities depending on the chemical form. The toxicity scale of arsenic decreases in the following order: arsine $>$ inorganic As $($ III $)>$ organic As(III) $>$ inorganic As $(\mathrm{V})>$ organic As $(\mathrm{V})$ $>$ arsonium compounds and elemental As. ${ }^{5}$ Compounds of As(III) are more toxic due to higher cellular uptake and a greater ability to bind to sulfhydryl groups of proteins, as well as forming free radicals causing oxidative stress. ${ }^{6}$

Concern regarding to the contamination of water by arsenic has gained importance after discovering the 
incident in Bangladesh, where thousands of people suffer from arsenicosis due to the consumption of water enriched with arsenic. Several other incidents around the world in many countries (Chile, China, India, Hungary, Mexico, Romania, Taiwan, Vietnam and others) have resulted in the inclusion of arsenic on the list of elements to be routinely measured in laboratory water analysis. Given the obvious risks of accumulation and chronic toxicological effects of arsenic in drinking water, in 1993, the World Health Organization (WHO) temporarily changed the maximum permissible limit from 50 to $10 \mu \mathrm{g} \mathrm{L}^{-1}$ of total arsenic in drinking water. ${ }^{7}$ In Brazil, the ordinance of the Ministry of Health, which normalizes quality of drinking water, also indicates a value of $10 \mu \mathrm{g} \mathrm{L}^{-1}$ of total As as the maximum allowed. ${ }^{8}$ Considering the risk to life and health caused by arsenic, there is growing interest in the use of low cost materials and methods for its removal from drinking water before it can cause significant contamination. ${ }^{9}$ In this context, several techniques are being developed to remove arsenic from water, including ion exchange, activated alumina, reverse osmosis, coagulation/filtration, reverse electrolysis and oxidation/filtration, in which solid phase adsorption appears to be a promising method..$^{10,11}$ Methods available for arsenic removal have been thoroughly reviewed. ${ }^{9}$ Among the materials used for adsorption of arsenic in the solid phase are, for example, mud, zeolites, activated alumina and hydrotalcite..$^{2,11-13}$ Materials used in the adsorption of arsenic from water include chitin and chitosan impregnated with molybdate, aluminum and iron ions. ${ }^{14-22}$ Several iron-containing materials are being more effectively used as adsorbents for arsenic compounds because of the advantages that they present mainly due to the formation of the very stable Fe:As complex..$^{18-24}$

Based on the fact that the $\mathrm{Fe}$ (III) presents high affinity for arsenic, this study initially focused on the synthesis of chitosan-iron in the form of beads which have high efficiency for removal of As(III) and As(V) from water. Thus, chitosan beads crosslinked with glutaraldehyde (Ch-CL) were initially synthesized. Next, the spheres formed were maintained in contact with a $\mathrm{FeCl}_{3}$ solution, resulting in immobilization of $\mathrm{Fe}(\mathrm{III})$. The dry Ch-FeCL beads formed presented an average diameter of $0.1 \mathrm{~mm}$ and were stable in air during development of the experimental part. Preparation of chitosan-iron from the initial mixture of $\mathrm{Fe}$ (III) salts with chitosan, in which a viscous gel is formed to later be dripped in a strong basic medium to form a precipitate in the form of spheres, showed less capacity to remove $\mathrm{As}(\mathrm{III})$ and $\mathrm{As}(\mathrm{V}){ }^{20-22}$

Thus air dried $\mathrm{Ch}-\mathrm{FeCL}$ beads were assessed as an adsorbent for $\mathrm{As}(\mathrm{III})$ and $\mathrm{As}(\mathrm{V})$ in aqueous solutions. The optimum conditions, equilibrium data, isotherms and the effect of temperature, adsorption kinetics, and competing ions including chloride, nitrate, sulfate and phosphate ions were obtained for $\mathrm{As}(\mathrm{III})$ and $\mathrm{As}(\mathrm{V})$. The Langmuir and Freundlich isotherms were fitted to the equilibrium adsorption data. Pseudo-first-order, pseudo-secondorder and intra-particle diffusion equations were adopted to test the experimental kinetic data. The reusability of the adsorbent was demonstrated. It was found in this study that the $\mathrm{Ch}-\mathrm{FeCL}$ was effective for $\mathrm{As}(\mathrm{III})$ and $\mathrm{As}(\mathrm{V})$ removal from experiments in batch and column settings. Finally, the dry $\mathrm{Ch}-\mathrm{FeCL}$ beads were used for decontamination of both $\mathrm{As}(\mathrm{III})$ and $\mathrm{As}(\mathrm{V})$ from surface and groundwater collected in the region of the Quadrilátero Ferrífero, Minas Gerais State, Brazil. In this region, arsenic concentrations exceeding $2200 \mu \mathrm{g} \mathrm{L}^{-1}$ have been observed in surface water and groundwater. ${ }^{25}$ The high levels of arsenic in water are related to both local lithology as well as past and present mining and smelting activities. ${ }^{25}$

\section{Experimental}

\section{Reagents and solutions}

All solutions were prepared with analytical grade reagents and high purity deionized water produced with a Milli-Q ${ }^{\circledR}$ system (Millipore, Bedford, MA, USA). The glassware and recipients for storage of the solutions were washed with neutral detergent, immersed in nitric acid $10 \%(\mathrm{v} / \mathrm{v})$ and rinsed with deionized water before use. A standard stock solution of $1000 \mathrm{mg} \mathrm{L}^{-1} \mathrm{As}$ (III) was prepared by dissolving $1.3203 \mathrm{~g}$ of $\mathrm{As}_{2} \mathrm{O}_{3}$ (Vetec, Rio de Janeiro) in $25 \mathrm{~mL}$ of potassium hydroxide $20 \%(\mathrm{~m} / \mathrm{v})$ followed by neutralization with sulfuric acid $20 \%$ (v/v) and further dilution to $1000 \mathrm{~mL}$ with $\mathrm{H}_{2} \mathrm{SO}_{4} 1 \%$ (v/v). A standard stock solution of $1000 \mathrm{mg} \mathrm{L}^{-1} \mathrm{As}(\mathrm{V})$ was prepared by dissolving $4.1645 \mathrm{~g}$ of $\mathrm{Na}_{2} \mathrm{HAsO}_{4} \cdot 7 \mathrm{H}_{2} \mathrm{O}$ (Vetec) and further diluted to $1.00 \mathrm{~L}$ with deionized water.

\section{Preparation of the Ch-FeCL beads}

Beads were prepared by dissolving $2 \mathrm{~g}$ of chitosan (low molecular weight, $75-85 \%$ deacetylated, Sigma Aldrich) in $50 \mathrm{~mL}$ of acetic acid $5 \%(\mathrm{~m} / \mathrm{v})$. The gel formed was agitated for $24 \mathrm{~h}$ until complete dissolution, after which the mixture was dripped into a $\mathrm{NaOH} 0.5 \mathrm{~mol} \mathrm{~L}^{-1}$ solution using a Masterflex ${ }^{\circledast}$ peristaltic pump, forming beads upon contact of the gel drops with the alkaline solution.

The beads remained in contact with the $\mathrm{NaOH}$ solution for $30 \mathrm{~min}$. After this time, they were washed with deionized water until the rinse water presented a pH 7.0. The polymer in the form of beads remained in contact 
with a glutaraldehyde $2.5 \%(\mathrm{v} / \mathrm{v})$ solution maintaining a ratio of $1.0 \mathrm{~g}$ of moist beads to $1.5 \mathrm{~mL}$ of solution for 24 h. Next, its complexation with $\mathrm{Fe}^{3+}$ ions was promoted via adaptation of the method proposed by Ngah et al. ${ }^{26}$ Crosslinked beads were placed in contact with a solution of $\mathrm{Fe}^{3+}$ under agitation; and this solution was prepared by dissolving a mass of $\mathrm{FeCl}_{3}$ obtaining a $\mathrm{Fe}^{3+}$ concentration in the proportion determined by

$[\mathrm{Fe}(\mathrm{III})]=\frac{\text { mass of moist crosslinked beads }(\mathrm{g}) \times 6 \mathrm{mg} \mathrm{L}^{-1} \mathrm{Fe}^{3+}}{0.010 \mathrm{~g} \text { of chitosan }}$

The system remained under agitation for $40 \mathrm{~min}$. After this period, the Ch-FeCL complex was agitated for the same period with deionized water in order to remove excess $\mathrm{Fe}(\mathrm{III})$ not complexed to the polymer surface. The final step of synthesis included drying the beads in an oven for $18 \mathrm{~h}$ at $45^{\circ} \mathrm{C}$. Dry Ch-FeCL beads presented an average diameter of $1 \mathrm{~mm}$ and were stable in air. These were stored in plastic bottles and used in the experiments.

\section{Characterization of $\mathrm{Ch}-\mathrm{FeCL}$}

The prepared materials were characterized by complementary techniques: X-ray diffractometry (XRD), Fourier transform infrared spectroscopy (FTIR) and determination of iron concentration in the $\mathrm{Ch}-\mathrm{FeCL}$ beads. X-ray diffraction analyses were performed with an XRD System model X' Pert PRO (PANalytical, Almelo, The Netherlands) using a $\mathrm{Ni}$ filter, $\mathrm{Co} \mathrm{K}_{\alpha}$ radiation $(\lambda=1.78890 \AA)$ and angular variation of $10-80^{\circ}(2 \theta)$. The infrared spectroscopy analysis was performed using a Perkin Elmer infrared spectrophotometer (FTIR 1000, Waltham, Massachusetts ) in the region of 400 to 4000 $\mathrm{cm}^{-1}$. To obtain pellets of the samples, approximately 1.50 mg were mixed with $100 \mathrm{mg} \mathrm{KBr}$ previously dried in an oven. After homogenization, the mixture was pressed in a hydraulic press to obtain $0.200 \mathrm{~mm}$ thick pellets. For analysis of iron, $0.2000 \mathrm{~g}$ of the $\mathrm{Ch}-\mathrm{FeCL}$ sample was weighted and subjected to acid digestion with $7.00 \mathrm{~mL}$ $\mathrm{HNO}_{3} 65 \%$ (m/m), $3.00 \mathrm{~mL} \mathrm{HCl} 37 \%(\mathrm{~m} / \mathrm{m}), 5.00 \mathrm{~mL} \mathrm{HF}$ $40 \%(\mathrm{~m} / \mathrm{m}), 5.00 \mathrm{~mL} \mathrm{H}_{2} \mathrm{O}$ and $1.00 \mathrm{~mL} \mathrm{H}_{2} \mathrm{O}_{2} 30 \%(\mathrm{~m} / \mathrm{m})$ in a microwave oven, increasing the temperature to $180{ }^{\circ} \mathrm{C}$ over $5 \mathrm{~min}(1000 \mathrm{~W})$ and maintaining this temperature for $10 \mathrm{~min}$. The samples were then filtered through quantitative filter paper and iron concentration was determined using an atomic absorption spectrometer (AAS).

\section{Determination of arsenic}

Quantification of arsenic was performed by hydride generation atomic absorption spectrometry (HG-AAS) using a Varian VGA77 hydride generator. The formation of hydrides was obtained using $\mathrm{NaBH}_{4} 0.6 \%(\mathrm{~m} / \mathrm{v})$ in $\mathrm{NaOH}$ $0.5 \%(\mathrm{~m} / \mathrm{v})$ and $6 \mathrm{~mol} \mathrm{~L}^{-1} \mathrm{HCl}$. Total arsenic was determined by the reduction of $\mathrm{As}(\mathrm{V})$ to $\mathrm{As}(\mathrm{III})$ via addition of $\mathrm{KI} 50 \%$ $(\mathrm{m} / \mathrm{v})$ and $6 \mathrm{~mol} \mathrm{~L}^{-1} \mathrm{HCl}$, obtaining concentrations of $10 \%$ $(\mathrm{m} / \mathrm{v})$ and $1 \mathrm{~mol} \mathrm{~L}^{-1}$ for the two reagents, respectively. For determination of $\mathrm{As}(\mathrm{III}), 250 \mathrm{~mL}$ of the sample and $2 \mathrm{~mL}$ of citrate buffer at $\mathrm{pH} 4.5$ were added. The concentration of $\mathrm{As}(\mathrm{V})$ was determined as the difference between total arsenic and As(III). ${ }^{27}$ All analyses were carried out in duplicate.

\section{Adsorption experiment}

\section{Effect of $\mathrm{pH}$}

The effect of $\mathrm{pH}$ on the adsorption process was studied in batch processing, using $10 \mathrm{~mL}$ solutions of $\mathrm{As}(\mathrm{III})$ or $\mathrm{As}(\mathrm{V})$ at concentrations of $75 \mathrm{mg} \mathrm{L}^{-1}$ and $50 \mathrm{mg}$ of adsorbent (mass obtained as optimum in studies on the effect of adsorbent doses). The $\mathrm{pH}$ value of the sample was adjusted in the range of 2 to 12 with diluted solutions of $\mathrm{HCl}$ and $\mathrm{NaOH}$. A portable digital pH meter (WTW brand, model 340i, Manchester, UK) equipped with combination electrodes of glass and silver/silver chloride, and automatic temperature correction accurate to three decimal places was used for determining $\mathrm{pH}$. The system was maintained under constant stirring in a thermostatically controlled system at $25 \pm 0.5^{\circ} \mathrm{C}$ for $24 \mathrm{~h}$. After this contact time, the adsorbent was separated from the solution by filtration, and the $\mathrm{pH}$ and arsenic concentrations were determined in the filtrate.

\section{Adsorption kinetics}

Evaluation of adsorption kinetics was carried out in batch processing under agitation in a thermostatically controlled system at $25 \pm 0.5{ }^{\circ} \mathrm{C}$. For the tests, $50 \mathrm{mg}$ of adsorbent and $10 \mathrm{~mL}$ of $\mathrm{As}(\mathrm{III})$ or $\mathrm{As}(\mathrm{V})$ at the concentration of $75 \mathrm{mg} \mathrm{L}^{-1}$ were used; and the $\mathrm{pH}$ of the solutions was adjusted to 7.0. The adsorbent was in contact for a time period ranging from 0-12 h. After the different contact times, the solutions were filtered and arsenic concentration was determined in the filtrate.

\section{Isotherms and the effect of temperature}

To obtain the adsorption isotherms, tests were done in batch using $10 \mathrm{~mL}$ solutions of $\mathrm{As}(\mathrm{III})$ or $\mathrm{As}(\mathrm{V})$ with concentrations ranging from 1 to $160 \mathrm{mg} \mathrm{L}^{-1}$ and $50 \mathrm{mg}$ of the adsorbent, adjusting the $\mathrm{pH}$ to 7.0. The solutions were kept under constant agitation in a system maintained at $25 \pm 0.5^{\circ} \mathrm{C}$ for a period of 2 and $3 \mathrm{~h}$ for $\mathrm{As}(\mathrm{V})$ and $\mathrm{As}(\mathrm{III})$, respectively (time of adsorption equilibrium). Enthalpy of adsorption was determined for the adsorption of $\mathrm{As}(\mathrm{V})$ by 
varying temperature among the values of 25, 30, 35, 40 and $45^{\circ} \mathrm{C}$. After the contact time, the solutions were filtered and the arsenic concentration was determined in the filtrate.

Effect of the interference of chloride, nitrate, sulfate and phosphate ions

The chloride, nitrate, sulfate and phosphate ions in this study were selected because they are commonly found in natural waters, where the presence of other ions in solution may cause competition for the $\mathrm{Fe}^{3+}$ adsorption site. In this study, it will be possible to obtain information on the specific adsorbent for arsenic species in the presence of these ions. Therefore, the interfering effect of common ions including chloride, nitrate, sulfate and phosphate ions on the adsorption capacity of As(III) or As(V) was evaluated using solutions with concentrations of 1, 10, 30 and $50 \mathrm{mmol} \mathrm{L}^{-1}$ for each ion and a concentration of As(III) or As(V) of $1 \mathrm{mmol} \mathrm{L}^{-1}\left(75 \mathrm{mg} \mathrm{L}^{-1}\right)$. The $\mathrm{pH}$ value of the solution was adjusted to 7.0, and the salts $\mathrm{NaCl}, \mathrm{NaNO}_{3}$, $\mathrm{Na}_{2} \mathrm{SO}_{4}$ and $\mathrm{KH}_{2} \mathrm{PO}_{4}$ were used in its preparation. Samples were maintained under agitation in a thermostatic bath at $25 \pm 0.5^{\circ} \mathrm{C}$ for 2 and $3 \mathrm{~h}$ for $\mathrm{As}(\mathrm{V})$ and $\mathrm{As}(\mathrm{III})$, respectively. After the contact time, the solutions were filtered and the arsenic concentration was determined in the filtrate.

\section{Desorption}

For desorption experiments, $50 \mathrm{mg}$ of the adsorbent were saturated with As(III) or As(V) in $75 \mathrm{mg} \mathrm{L}^{-1}$ solutions whose $\mathrm{pH}$ had been adjusted to 7.0. After 2 and $3 \mathrm{~h}$ of contact for As(V) and As(III), respectively, washing cycles of the adsorbent were performed to remove the excess As(III) or As(V) not adsorbed. Next, $5 \mathrm{~mL}$ of the desorbent solutions were added and agitated for $12 \mathrm{~h}$. Desorbent solutions used were citric, hydrochloric and tartaric acids at concentrations of $10^{-2}, 10^{-1}$ and $1.00 \mathrm{~mol} \mathrm{~L}^{-1}$. After this contact time, the solutions were filtered and the arsenic concentrations were determined in the filtrates.

\section{Column study}

The column study was conducted to evaluate the use of $\mathrm{Ch}-\mathrm{FeCL}$ as a low cost technology for removal of $\mathrm{As}(\mathrm{III})$ and $\mathrm{As}(\mathrm{V})$ from contaminated waters. Experiments were performed in a column measuring $0.5 \mathrm{~cm}$ in inner diameter, filled with 0.25 and $1.0 \mathrm{~g}$ to give a bed height of 5 and $20 \mathrm{~cm}$ of Ch-FeCL beads for As(V) and As(III), respectively. The influent solution presented a As(V) concentration of $0.5 \mathrm{mg} \mathrm{L}^{-1}$ at $\mathrm{pH} 7.0$ and was percolated through the column at a flow rate of $2 \mathrm{ml} \mathrm{min}^{-1}$. Samples of the effluent solution were collected to determine the concentrations of As(III) and As(V).

\section{Results and Discussion}

\section{Characteristics of $\mathrm{Ch}-\mathrm{FeCL}$}

The XRD analyses were performed for crosslinked chitosan (Ch-CL) and Ch-FeCL bead samples. In the diffractogram of Figure 1, four characteristic peaks of $2 \theta$ between 9 and $25^{\circ}$ were observed for the crosslinked chitosan. The peaks between 9 and $13^{\circ}$ are related to the amorphous portion of the chitosan structure due to the presence of random amino groups $\left(\mathrm{NH}_{2}^{-}\right)$, and the peak in the $2 \theta$ region between 15 and $25^{\circ}$ is related to the crystalline portion of the biopolymer structure, resulting from packing of the polymer chain and their inter-chain interactions. ${ }^{28}$ The diffractogram of Ch-FeCL presented a crystallinity index much lower than that of Ch-CL. According to Webster et al. ${ }^{29}$ the interactions between biopolymers with chitosan and metal ions such as $\mathrm{Cr}(\mathrm{VI}), \mathrm{Ni}(\mathrm{II}), \mathrm{Fe}(\mathrm{II})$ and $\mathrm{Fe}$ (III) affect the crystallinity, resulting in the formation of new crystalline phases via new covalent bonds between the biopolymer and the ions or organic molecules.

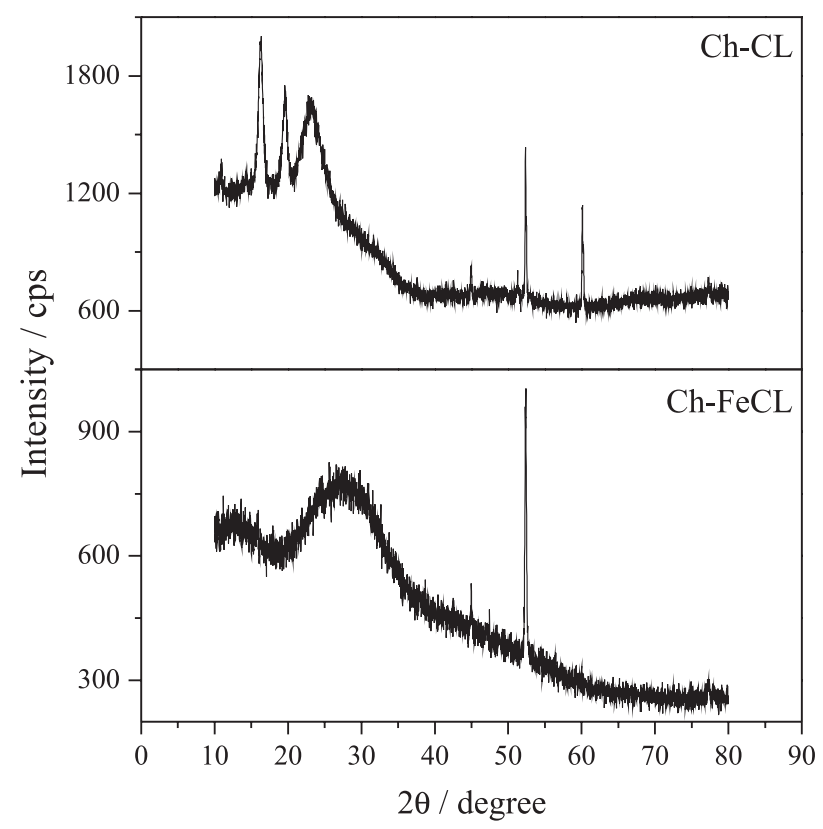

Figure 1. XRD patterns of crosslinked chitosan (Ch-CL) and crosslinked chitosan-Fe(III) (Ch-FeCL).

Figure 2 shows the FTIR spectra of Ch-FeCL before and after As(III) and As(V) adsorption. The broad and strong band at the wavenumber region $3300-3500 \mathrm{~cm}^{-1}$ is characteristic of the $-\mathrm{NH}$ stretching vibration. ${ }^{30}$ Due to the crosslinking of chitosan, a peak at $1650 \mathrm{~cm}^{-1}$ is observed corresponding to stretching vibrations of $\mathrm{C}=\mathrm{N}$ bond. This peak indicated the formation of Schiff's base as a result of the reaction between 
carbonyl group of glutaraldehyde and the amine group of chitosan. ${ }^{19}$ The deformation band of the primary amine $(-\mathrm{NH})$ appears in $1560 \mathrm{~cm}^{-1}$, the band corresponding to axial deformation of the $\mathrm{C}-\mathrm{N}$ amide appears with low intensity at $1430 \mathrm{~cm}^{-1}$. At $1020 \mathrm{~cm}^{-1}$, it is the band indicating a stretching of the $\mathrm{C}-\mathrm{OH}$ group of the primary alcohol and an asymmetric $\mathrm{C}-\mathrm{O}-\mathrm{C}$ stretching band in the $1145 \mathrm{~cm}^{-1}$ region, defined by the $\beta-1-4$ glycosidic bond in the polymer chain. At $1100 \mathrm{~cm}^{-1}$, it is a band of aliphatic amines. The axial deformation band $-\mathrm{CN}$ of the amino group appears at approximately $1320 \mathrm{~cm}^{-1} .^{30} \mathrm{In}$ the Ch-FeCL spectrum, two characteristic bands of iron complexation appear at $580 \mathrm{~cm}^{-1}$ due to stretching of the $\mathrm{Fe}-\mathrm{N}$ bond and another at $460 \mathrm{~cm}^{-1}$ related to stretching of the $\mathrm{Fe}-\mathrm{O}$ bond. The bands at $892 \mathrm{~cm}^{-1} \mathrm{of} \mathrm{Ch}-\mathrm{FeCL}$ after the adsorption of arsenite and asenate match well with the stretching frequencies of $\mathrm{As}-\mathrm{O}$ in the $\mathrm{H}_{2} \mathrm{AsO}_{4}{ }^{-}$group. ${ }^{19}$

The amount of iron determined by FAAS in the dry Ch-FeCL beads was $6.45 \mathrm{mg} \mathrm{g}^{-1}$.

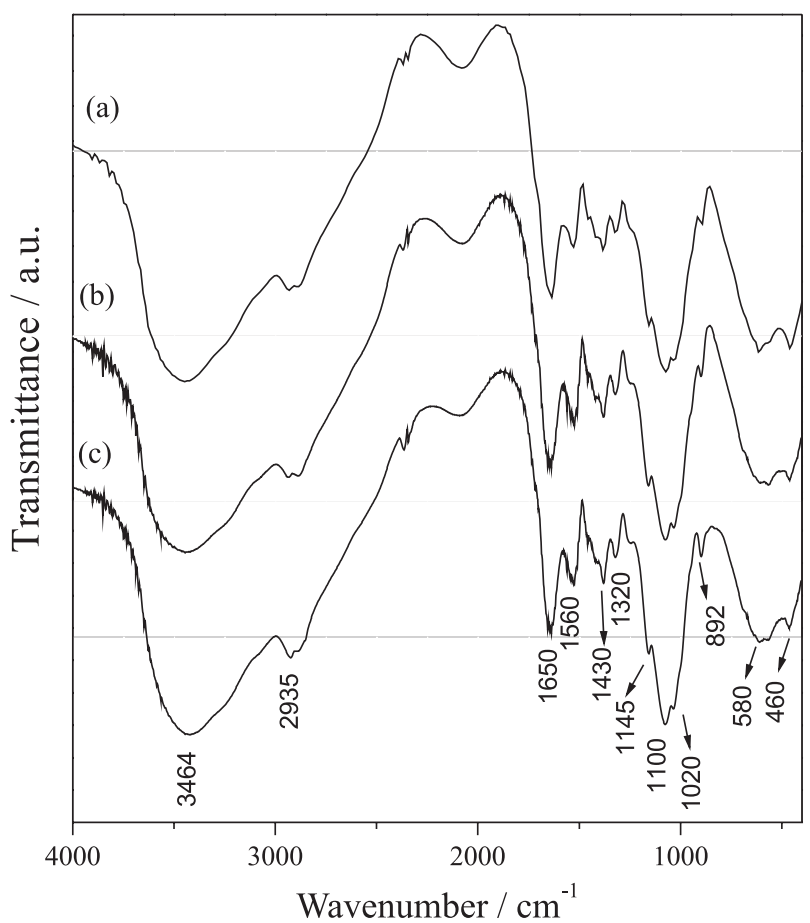

Figure 2. FTIR spectra of Ch-FeCL (a) before, and after loading with (b) As(III) and (c) As(V).

\section{Effect of initial $\mathrm{pH}$}

The adsorption percentage of As(III) and As(V) by $\mathrm{Ch}-\mathrm{FeCL}$ depending on the initial $\mathrm{pH}$ is presented in Figure 3. It can be observed in Figure 3 that the adsorption of $\mathrm{As}(\mathrm{V})$ by the adsorbent presents low efficiencies at $\mathrm{pH}$ values both very low $(\mathrm{pH}<2)$ and very high $(\mathrm{pH}>10)$, in which the best results are between 6-8.

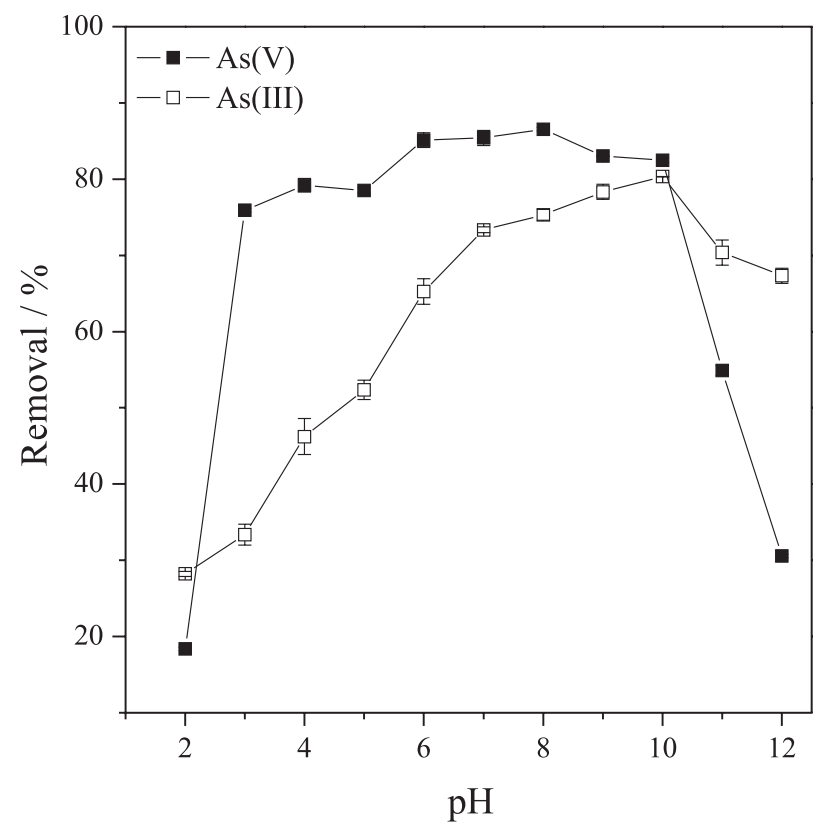

Figure 3. Effect of $\mathrm{pH}$ on adsorption of $\mathrm{As}(\mathrm{III})$ and $\mathrm{As}(\mathrm{V})$ by $\mathrm{Ch}-\mathrm{FeCL}$. Conditions: initial concentration of As(III) and As(V) $75 \mathrm{mg} \mathrm{L}^{-1}$; time $=24 \mathrm{~h}$

The explanation for this behavior is related to the distribution of $\mathrm{As}(\mathrm{V})$ species in the aqueous medium, in which a decrease in $\mathrm{pH}$ increases the amount of $\mathrm{H}_{3} \mathrm{AsO}_{4}$, at $\mathrm{pH} 3-4$, the predominant arsenic specie are $\mathrm{H}_{2} \mathrm{AsO}_{4}^{-}$, and at $\mathrm{pH} 4$ to 10 , the arsenic species are controlled by the equilibrium $\mathrm{H}_{2} \mathrm{AsO}_{4}{ }^{-} \leftrightarrows \mathrm{HAsO}_{4}{ }^{2-}+\mathrm{H}^{+}(\mathrm{pKa} 6.7){ }^{31}$

Chitosan has a point of zero charge $\left(\mathrm{pH}_{\mathrm{pzc}}\right)$ at $\mathrm{pH} 6.3$, and $99 \%$ of total amino groups protonated at $\mathrm{pH}$ 4.3. With the increase in $\mathrm{pH}$, the charge of the adsorbent becomes less positive. At $\mathrm{pH}>\mathrm{pH}_{\mathrm{pzc}}$, its surface becomes negatively charged, so that it repels the anionic species. ${ }^{32}$ Thus, it can be concluded that as $\mathrm{pH}$ increases, there occurs formation of deprotonated $\mathrm{As}(\mathrm{V})$ species in the form of oxyanions $\left(\mathrm{H}_{2} \mathrm{AsO}_{4}{ }^{-}, \mathrm{HAsO}_{4}{ }^{2-}\right)$ which are adsorbed by the positive adsorption site generated by iron complexed with chitosan. ${ }^{4}$ At $\mathrm{pH}>10$, adsorption is hindered by competition between hydroxyls in the medium for adsorption sites. Maximum adsorption at $\mathrm{pH} 7$ has been reported for $\mathrm{As}(\mathrm{V})$ in studies involving the removal of arsenic with iron-coated materials. ${ }^{18,19}$ In Figure 3, it can be observed that there is a marked increase in the removal of $\mathrm{As}(\mathrm{III})$ up to $\mathrm{pH} 7$ and maximum adsorption is reached at pH 10 (removal percentage similar to As(V)). The As(III) species in aqueous medium and in the $\mathrm{pH}$ interval of 3-11 are controlled by $\mathrm{H}_{3} \mathrm{AsO}_{3} \leftrightarrows \mathrm{H}_{2} \mathrm{AsO}_{3}^{-}+\mathrm{H}^{+}(\mathrm{pKa} 9.22) .{ }^{31}$ At $\mathrm{pH}$ greater than 9, $\mathrm{As}$ (III) is present exclusively as an anion, while at $\mathrm{pH}$ 6-9 only a small percentage of $\mathrm{H}_{3} \mathrm{AsO}_{3}$ is dissociated..$^{33}$ The uncharged $\mathrm{As}(\mathrm{III})$ species $\left(\mathrm{H}_{3} \mathrm{AsO}_{3}\right)$ cannot undergo electrostatic interaction with 
the adsorvent. As(III) species can undergo only Lewis acid-base interaction and adsorption occurs by inner-sphere complexation mechanism with $\mathrm{Fe}(\mathrm{III}){ }^{33}$ Therefore, at $\mathrm{pH}$ greater than 9, As(III) can be adsorbed by $\mathrm{Ch}-\mathrm{FeCL}$ owing to electrostatic interactions with the positive site generated by $\mathrm{Fe}(\mathrm{III})$ complexed with chitosan. Final $\mathrm{pH}$ measured after reaching adsorption equilibrium for the entire $\mathrm{pH}$ range studied did not change, showing that the adsorbent presented stability at extreme $\mathrm{pH}$ values.

Considering that one of the objectives of this study is the use of dry adsorbent (Ch-FeCL) in the removal of both $\mathrm{As}(\mathrm{III})$ and $\mathrm{As}(\mathrm{V})$ from surface and groundwater, which have a pH near neutral, all studies were performed at $\mathrm{pH}$ 7.0.

\section{Adsorption kinetics}

The kinetic adsorption process was carried out to verify the rate at which the $\mathrm{Ch}$-FeCL polymer adsorbed $\mathrm{As}(\mathrm{IIII})$ and $\mathrm{As}(\mathrm{V})$. Adsorption of arsenic by $\mathrm{Ch}-\mathrm{FeCL}$ is dependent on contact time. A rapid decay in initial concentration during the beginning was observed for both $\mathrm{As}(\mathrm{V})$ and $\mathrm{As}(\mathrm{III})$ ( $90 \%$ reduction), in which the equilibrium was achieved after $2 \mathrm{~h}$ of contact for $\mathrm{As}(\mathrm{V})$ and $3 \mathrm{~h}$ for As(III) (Figure 4). This fact demonstrates that the As(III) adsorption process is slower than that of $\mathrm{As}(\mathrm{V})$.

\section{Mathematical models of adsorption kinetics}

Pseudo-first order Lagergren, pseudo-second order kinetic and intraparticle diffusion models were studied to examine the mechanism that controls the adsorption process. ${ }^{34-36}$ Validity of these models can be assessed by the linear graphs of each equation: $\log \left(\mathrm{q}_{\mathrm{e}}-\mathrm{q}_{\mathrm{t}}\right) v s$. $\mathrm{t}$ for the pseudo-first order model (equation 1), $t / \mathrm{q}_{\mathrm{t}} v s . \mathrm{t}$ for the pseudo-second order model (equation 2) and $\mathrm{q}_{\mathrm{t}} v s . \mathrm{t}^{0.5}$ for the intraparticle diffusion model (equation 3). Kinetic parameters of the adsorption process of $\mathrm{As}(\mathrm{III})$ and $\mathrm{As}(\mathrm{V})$ by $\mathrm{Ch}-\mathrm{FeCL}$ were obtained by linear regression of the graphs for each model $\left(\mathrm{R}^{2}\right)$ and by the calculated $\mathrm{q}_{\mathrm{e}}$ vs. experimental $\mathrm{q}_{\mathrm{e}}$

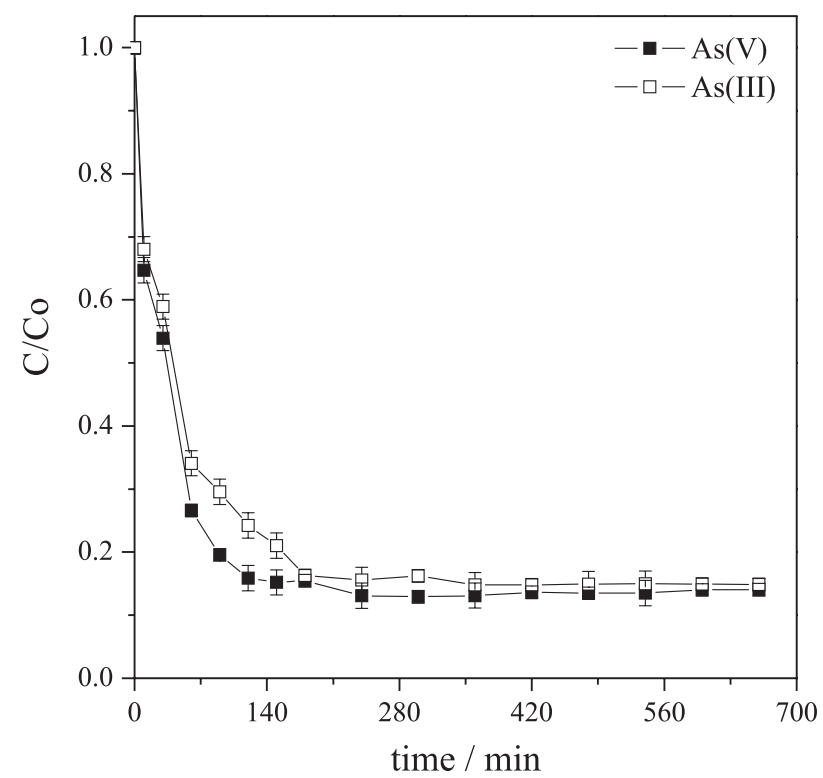

Figure 4. Kinetics of adsorption of $\mathrm{As}(\mathrm{III})$ and $\mathrm{As}(\mathrm{V})$ by Ch-FeCL. Conditions: initial concentration $\left(\mathrm{C}_{\mathrm{o}}\right)$ of $\mathrm{As}(\mathrm{III})$ and $\mathrm{As}(\mathrm{V}) 75 \mathrm{mg} \mathrm{L}^{-1}$.

(Table 1). Quantitative evaluation of the models was done by comparing the correlation coefficients. The pseudofirst order equation based on the adsorption of solute from solution can be expressed as:

$\log \left(q_{e}-q_{t}\right)=\log q_{e}-\frac{k_{1} t}{2.303}$

where $k_{1}$ is the rate constant of pseudo-first-order adsorption $\left(\mathrm{min}^{-1}\right), \mathrm{q}_{\mathrm{e}}\left(\mathrm{mg} \mathrm{g}^{-1}\right)$ and $\mathrm{q}_{\mathrm{t}}\left(\mathrm{mg} \mathrm{g}^{-1}\right)$ are the amounts of $\mathrm{As}(\mathrm{III})$ and $\mathrm{As}(\mathrm{V})$ adsorbed at equilibrium and the instant $t$ ( $\mathrm{min}$ ). The results showed that the adsorption process that best fits the experimental data $\left(\mathrm{R}^{2}>0.999\right)$ was the pseudo-second order model (Figure 5a). The pseudo-second order model is described by equation 2 , in which $\mathrm{k}_{2}$ is the rate constant of pseudo-second-order adsorption $\left(\mathrm{g} \mathrm{mg}^{-1} \mathrm{~min}^{-1}\right)$. This model shows chemisorption or activated mechanical adsorption as a determining step in the adsorption mechanism and not a mass transfer in solution. ${ }^{37}$

Table 1. Kinetic parameters for adsorption of As(III) and As(V) on Ch-FeCL

\begin{tabular}{|c|c|c|c|c|c|c|c|c|c|c|}
\hline & \multirow[b]{2}{*}{$\begin{array}{l}\mathrm{q}_{\mathrm{e}}, \exp / \\
\left(\mathrm{mg} \mathrm{g}^{-1}\right)\end{array}$} & \multirow{2}{*}{$\begin{array}{c}\mathrm{q}_{\mathrm{e}} / \\
\left(\mathrm{mg} \mathrm{g}^{-1}\right)\end{array}$} & \multicolumn{2}{|c|}{ Pseudo-first-order } & \multicolumn{3}{|c|}{ Pseudo-second-order } & \multicolumn{3}{|c|}{ Intra-particle diffusion } \\
\hline & & & $\begin{array}{c}\mathrm{k}_{1} \times 10^{-3} / \\
\min ^{-1}\end{array}$ & $\mathrm{R}^{2}$ & $\begin{array}{c}\mathrm{k}_{2} \times 10^{-3} / \\
\left(\mathrm{g} \mathrm{mg}^{-1} \min ^{-1}\right)\end{array}$ & $\begin{array}{c}\mathrm{q}_{\mathrm{e}} / \\
\left(\mathrm{mg} \mathrm{g}^{-1}\right)\end{array}$ & $\mathrm{R}^{2}$ & $\begin{array}{c}\mathrm{k}_{\mathrm{id}} / \\
\left(\mathrm{mg} \mathrm{g}^{-1} \min ^{-0.5}\right)\end{array}$ & $\begin{array}{c}\mathrm{C} / \\
\left(\mathrm{mg} \mathrm{g}^{-1}\right)\end{array}$ & $\mathrm{R}^{2}$ \\
\hline $\mathrm{As}(\mathrm{III})$ & 12.10 & 3.84 & 6.47 & 0.801 & 3.86 & 13.45 & 0.999 & 0.815 & 2.37 & 0.990 \\
\hline \multirow[t]{2}{*}{$\operatorname{As}(\mathrm{V})$} & 12.89 & 0.094 & 5.76 & 0.375 & 7.09 & 13.24 & 0.999 & $0.987^{\mathrm{a}}$ & 2.23 & 0.994 \\
\hline & & & & & & & & $0.016^{\mathrm{b}}$ & 13.32 & 0.910 \\
\hline
\end{tabular}

${ }^{a}$ First and; ${ }^{b}$ second linear region. $\mathrm{q}_{\mathrm{e}}$, exp: experimental values for the quantities of adsorbed at equilibrium; $\mathrm{q}_{\mathrm{e}}$ : quantity of ions adsorbed at equilibrium; $\mathrm{k}_{\mathrm{id}}$ : intraparticle diffusion coefficient; C: constant related to diffusion resistance. 
$\frac{1}{\mathrm{q}_{\mathrm{t}}}=\frac{1}{\mathrm{k}_{2} \mathrm{q}_{\mathrm{e}}^{2}}+\frac{1}{\mathrm{q}_{\mathrm{e}}} \mathrm{t}$

The quantities of As(III) and As(V) adsorbed at equilibrium $\left(\mathrm{q}_{\mathrm{e}}\right)$ calculated from the pseudo-second order equation and the experimental values $\left(\mathrm{q}_{\mathrm{e}}\right.$, exp) (Table 1) present results with similar values, confirming fit of the pseudo-second order model to this experiment and, consequently, in the control of rate a chemisorption or activated adsorption mechanism must be involved. ${ }^{35,37}$

The intraparticle diffusion coefficient $\left(\mathrm{k}_{\mathrm{id}}\right)$ is determined by equation 3 :

$\mathrm{q}_{\mathrm{t}}=\mathrm{k}_{\mathrm{id}} \mathrm{t}^{0.5}+\mathrm{C}$

where $\mathrm{q}_{\mathrm{t}}$ is the amount of $\mathrm{As}(\mathrm{III})$ and $\mathrm{As}(\mathrm{V})$ adsorbed $\left(\mathrm{mg} \mathrm{g}^{-1}\right), \mathrm{t}(\mathrm{min})$ is the agitation time and $\mathrm{C}\left(\mathrm{mg} \mathrm{g}^{-1}\right)$ is
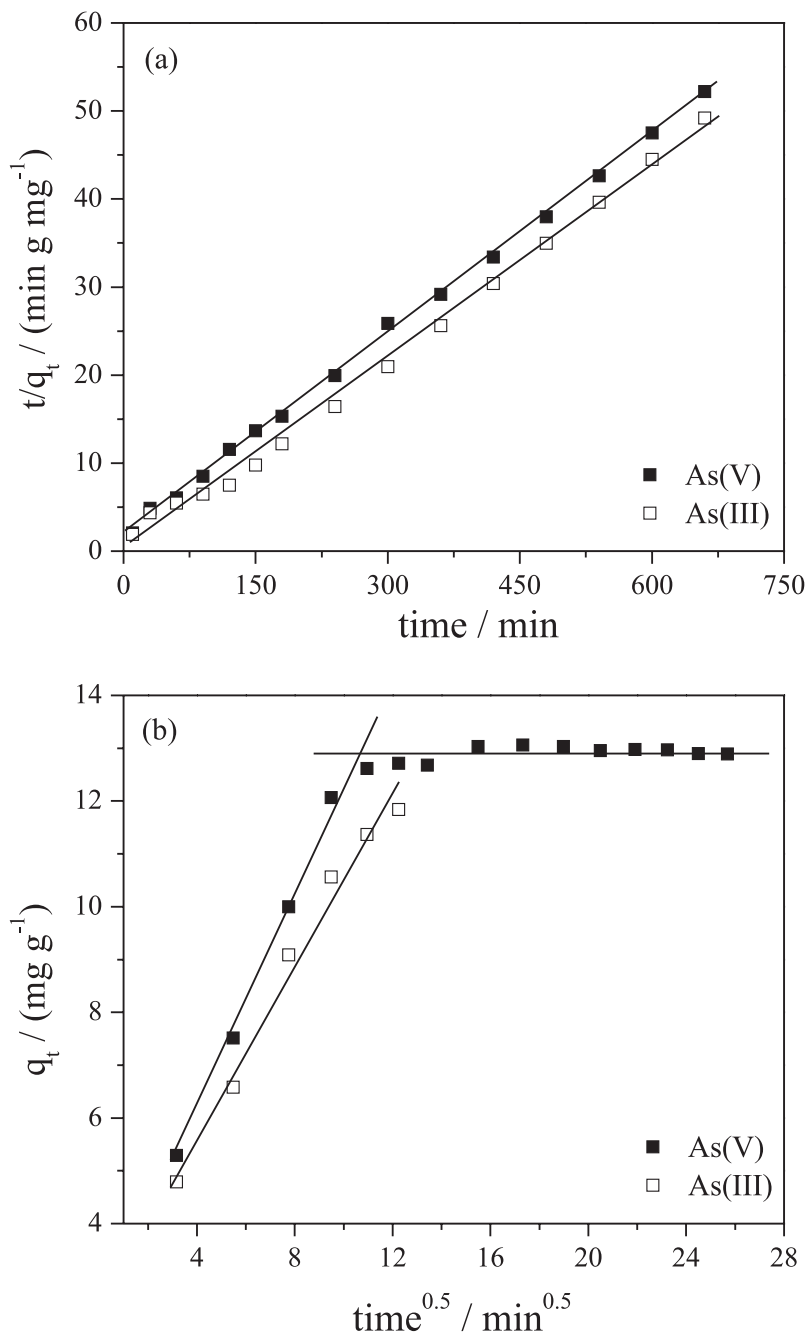

Figure 5. (a) Pseudo-second-order kinetic model and (b) intra-particle kinetic diffusion model for adsorption of $\mathrm{As}(\mathrm{III})$ and $\mathrm{As}(\mathrm{V})$ onto $\mathrm{Ch}-\mathrm{FeCL}$. Conditions: initial concentration of $\mathrm{As}(\mathrm{V}) 75 \mathrm{mg} \mathrm{L}^{-1}$; time $=3 \mathrm{~h}$ for $\mathrm{As}(\mathrm{III})$ and $2 \mathrm{~h}$ for $\mathrm{As}(\mathrm{V})$. a constant related to diffusion resistance. According to equation 3, the values of $\mathrm{k}_{\mathrm{id}}\left(\mathrm{mg} \mathrm{g}^{-1} \min ^{-0.5}\right)$ and $\mathrm{C}$ can be obtained from the slope of the $\mathrm{q}_{\mathrm{t}} v s . \mathrm{t}^{0.5}$ graph, respectively (Figure 5b). The values of $\mathrm{C}$ (Table 1) provide an estimate of the boundary layer thickness, i.e., the greater the value of $\mathrm{C}$, greater is the effect of the boundary layer..$^{38}$ There are studies indicating that the graph can present multi-linearity, which characterizes different stages of adsorption: external mass transfer followed by intraparticle diffusion in the macro, meso and micropore. ${ }^{39}$ Figure 5b shows that the lines of the $\mathrm{q}_{\mathrm{t}} v s . \mathrm{t}^{0.5}$ graph for As(III) and As(V) do not pass through the origin, indicating that the mechanism of intraparticle diffusion is not the only limiting step of the adsorption process and that other interaction mechanisms must be acting simultaneously. It was also noted that there are two linearities for $\mathrm{As}(\mathrm{V})$, in which the first represents instantaneous adsorption or external adsorption and second, the stage of gradual adsorption by intraparticle diffusion. ${ }^{36}$

Isotherms and the effect of temperature

The amount of arsenic adsorbed per unit mass of $\mathrm{Ch}-\mathrm{FeCL}\left(\mathrm{q}_{\mathrm{e}}\right.$ in $\left.\mathrm{mg} \mathrm{g}^{-1}\right)$ was correlated with the concentration in the liquid phase at equilibrium at a constant temperature $\left(\mathrm{C}_{\mathrm{e}}\right.$ in $\left.\mathrm{mg} \mathrm{L}^{-1}\right)$, using the Langmuir and Freundlich adsorption isotherms.

The Langmuir linear expression is given by equation 4 :

$\frac{\mathrm{C}_{\mathrm{e}}}{\mathrm{q}_{\mathrm{t}}}=\frac{1}{\mathrm{Q}_{\max } \mathrm{b}}+\frac{\mathrm{C}_{\mathrm{e}}}{\mathrm{Q}_{\max }}$

where $\mathrm{C}_{\mathrm{e}}$ is the concentration of $\mathrm{As}(\mathrm{III})$ or $\mathrm{As}(\mathrm{V})$ ions at equilibrium $\left(\mathrm{mg} \mathrm{L}^{-1}\right), \mathrm{q}_{\mathrm{e}}$ the amount adsorbed at equilibrium $\left(\mathrm{mg} \mathrm{g}^{-1}\right), \mathrm{Q}_{\max }$ the constant related to maximum adsorption capacity $\left(\mathrm{mg} \mathrm{g}^{-1}\right)$ and $\mathrm{b}$ the constant related to adsorption energy $\left(\mathrm{L} \mathrm{mg}^{-1}\right)$. The parameter $\mathrm{R}_{\mathrm{L}}$ (equation 5) is a dimensionless constant denominated the equilibrium parameter, which is defined as:

$\mathrm{R}_{\mathrm{L}}=\frac{1}{1+\mathrm{b} \mathrm{C}_{0}}$

where $\mathrm{C}_{0}$ is the initial greater concentration $\left(\mathrm{mg} \mathrm{L}^{-1}\right)$ and $\mathrm{b}$ is the Langmuir constant. The value of $R_{L}$ between 0 and 1 indicates favorable adsorption.

The linear Freundlich expression is given by equation 6 :

$\log \mathrm{q}_{\mathrm{e}}=\log \mathrm{k}_{\mathrm{f}}+\frac{1}{\mathrm{n}} \log \mathrm{C}_{\mathrm{e}}$

where $\mathrm{q}_{\mathrm{e}}$ is the quantity of ions adsorbed at equilibrium $\left(\mathrm{mg} \mathrm{g}^{-1}\right), \mathrm{C}_{\mathrm{e}}$ is the concentration of $\mathrm{As}(\mathrm{III})$ or $\mathrm{As}(\mathrm{V})$ ions in 
Table 2. Parameters of the Langmuir and Freundlich isotherms for adsorption of As(III) and As(V) by Ch-FeCL

\begin{tabular}{|c|c|c|c|c|c|c|c|}
\hline \multirow{2}{*}{ Temperature / K } & \multicolumn{4}{|c|}{ Langmuir model } & \multicolumn{3}{|c|}{ Freundlich model } \\
\hline & $\mathrm{R}_{\mathrm{L}}$ & $\mathrm{b} /\left(\mathrm{L} \mathrm{mg}^{-1}\right)$ & $\mathrm{Q}_{\max } /\left(\mathrm{mg} \mathrm{g}^{-1}\right)$ & $\mathrm{R}^{2}$ & $\mathrm{~K}_{\mathrm{f}} /\left(\mathrm{L} \mathrm{mg}^{-1}\right)$ & $\mathrm{n}$ & $\mathrm{R}^{2}$ \\
\hline $298^{a}$ & 0.038 & 0.1570 & 21.24 & 0.975 & 4.872 & 2.743 & 0.987 \\
\hline $298^{\mathrm{b}}$ & 0.048 & 0.1252 & 27.59 & 0.954 & 5.9706 & 2.6099 & 0.986 \\
\hline $303^{\mathrm{b}}$ & 0.078 & 0.0859 & 25.98 & 0.995 & 3.5123 & 2.1731 & 0.990 \\
\hline $308^{\mathrm{b}}$ & 0.086 & 0.0667 & 19.90 & 0.982 & 2.1117 & 2.0013 & 0.988 \\
\hline $313^{\mathrm{b}}$ & 0.119 & 0.0462 & 20.98 & 0.997 & 1.9792 & 1.9970 & 0.976 \\
\hline $318^{\mathrm{b}}$ & 0.146 & 0.0365 & 17.64 & 0.980 & 1.3929 & 1.8754 & 0.995 \\
\hline
\end{tabular}

${ }^{\mathrm{a}} \mathrm{As}(\mathrm{III}) ;{ }^{\mathrm{b}} \mathrm{As}(\mathrm{V})$; $\mathrm{q}_{\mathrm{e}}$ : quantity of ions adsorbed at equilibrium; $\mathrm{R}_{\mathrm{L}}$ : equilibrium parameter; b: Langmuir constant; $\mathrm{Q}_{\max }$ : constant related to maximum adsorption capacity; $K_{\mathrm{f}}$ : constant related to the adsorption capacity; 1/n: the Freundlich constant.

the liquid phase at equilibrium $\left(\mathrm{mg} \mathrm{L}^{-1}\right), \mathrm{k}_{\mathrm{f}}$ is the constant related to the adsorption capacity $\left(\mathrm{L} \mathrm{mg}^{-1}\right)$ and $1 / \mathrm{n}$ is the Freundlich constant. Values of $\mathrm{n}$ between 1 and 10 represent favorable adsorption. The Langmuir and Freundlich constants were determined by linear regression of the linearized equations and presented for $\mathrm{Ch}-\mathrm{FeCL}$ in Table 2.

Estimates of the Langmuir parameters showed good applicability of this model for adsorption of As(III) and $\mathrm{As}(\mathrm{V})$ by $\mathrm{Ch}-\mathrm{FeCL}$, in which from the constant value of $\mathrm{b}$, a good affinity of the adsorbate to the adsorbent can be observed, also being confirmed by the dimensionless separation factor $\left(\mathrm{R}_{\mathrm{L}}\right)$ calculated for $\mathrm{As}(\mathrm{III})$ at $25^{\circ} \mathrm{C}$ $(298 \mathrm{~K})$ and $\mathrm{As}(\mathrm{V})$ in the temperature range from $25^{\circ} \mathrm{C}$ (298 K) to $45^{\circ} \mathrm{C}(318 \mathrm{~K})$ (Table 2).

The adsorption of $\mathrm{As}(\mathrm{III})$ and $\mathrm{As}(\mathrm{V})$ by $\mathrm{Ch}-\mathrm{FeCL}$ can also be explained by the Freundlich model. Values of $n$ are between 1 and 10, indicating a favorable adsorption, as shown in Table 2. Thus, both models can be used to explain the adsorption of $\mathrm{As}(\mathrm{III})$ and $\mathrm{As}(\mathrm{V})$ by $\mathrm{Ch}-\mathrm{FeCL}$ beads. The adsorption capacities of $\mathrm{Ch}-\mathrm{FeCL}$ estimated by the Langmuir adsorption model at $25^{\circ} \mathrm{C}(298 \mathrm{~K})$ were 21.24 and $27.59 \mathrm{mg} \mathrm{g}^{-1}$ for $\mathrm{As}(\mathrm{III})$ and $\mathrm{As}(\mathrm{V})$, respectively. Adsorption by $\mathrm{Ch}-\mathrm{FeCL}$ showed a good efficiency in $\mathrm{pH} 7.0$ when compared with other adsorbents employing modified chitosan for the removal of As(III) and As(V).

Boddu et al. ${ }^{17}$ using alumina coated with chitosan showed adsorption capacities at $\mathrm{pH} 4.0$ of 56.40 and $96.46 \mathrm{mg} \mathrm{g}^{-1}$ for As(III) and As(V), respectively. Although this adsorbent shows a high adsorption capacity, its efficiency must be evaluated in the presence of various interfering ions and with groundwater and surface water contaminated with arsenic. Chitosan impregnated with molybdate has also been used to remove $\mathrm{As}(\mathrm{III})$ and $\mathrm{As}(\mathrm{V})$ in water samples. ${ }^{16}$ Although this adsorbent is efficient and presents adsorption capacities of 1.98 and $2.00 \mathrm{mg} \mathrm{g}^{-1}$ for As(III) and As(V), respectively, the phosphate ion causes serious interference, in which the removal of arsenic does not occur in the presence of phosphate. Gupta et al. ${ }^{19}$ studied the chitosaniron composite in the form of flakes and granules for removal of arsenic from groundwater. The capacities of the flakes (16.15 mg g ${ }^{-1}$ for As(III) and $22.47 \mathrm{mg} \mathrm{g}^{-1}$ for As(V)) were significantly higher when compared to the granules (2.32 $\mathrm{mg} \mathrm{g}^{-1}$ for As(III) and $2.24 \mathrm{mg} \mathrm{g}^{-1}$ for As(V)), both of which were obtained at $\mathrm{pH}$ 7.0.

The Ch-FeCL beads developed in the present study showed greater adsorption at $\mathrm{pH} 7.0$ when compared with those made of the chitosan-iron composite. ${ }^{20-22}$ The synthesis process used in this study, in which the chitosan beads are first prepared and subsequently maintained in contact with a $\mathrm{FeCl}_{3}$ solution for immobilization of $\mathrm{Fe}(\mathrm{III})$, resulted in increased adsorption capacity. This is possibly due to increased porosity of the adsorbent material which facilitates the migration of ions through the pores, collaborating with intraparticle adsorption.

Thus, the main advantage of the adsorbent in the form of beads as developed in this study is that it is stable in air after the drying process, can be easily removed from the solution by filtration (diameter of $1 \mathrm{~mm}$ ) and permits the removal of $\mathrm{As}(\mathrm{III})$ and $\mathrm{As}(\mathrm{V})$ at neutral $\mathrm{pH}$.

Changes in the adsorption process caused by temperature were evaluated using the thermodynamic parameters determined by the Langmuir isotherm. Thermodynamic parameters such as changes in Gibbs energy $\left(\Delta \mathrm{G}^{\circ}\right)$, enthalpy $\left(\Delta \mathrm{H}^{\circ}\right)$ and entropy $\left(\Delta \mathrm{S}^{\circ}\right)$ are calculated using equations 7 and 8:

$\Delta \mathrm{G}^{\mathrm{o}}=-\mathrm{RT} \ln \mathrm{b}$

$\ln \mathrm{b}=\frac{\Delta \mathrm{G}^{\mathrm{o}}}{\mathrm{R}}+\frac{\Delta \mathrm{H}^{\mathrm{o}}}{\mathrm{RT}}$

where $\mathrm{R}$ is the ideal gas constant $\left(8.314 \mathrm{~J} \mathrm{~mol}^{-1} \mathrm{~K}^{-1}\right)$, $\mathrm{T}$ is temperature in Kelvin $(\mathrm{K})$ and $\mathrm{b}$ is the Langmuir constant $\left(\mathrm{L} \mathrm{mol}^{-1}\right) . \Delta \mathrm{H}^{\circ}$ and $\Delta \mathrm{S}^{\circ}$ are calculated from the 
slope and intercept of the van't Hoff plot for log b versus $1 / \mathrm{T}$. The calculated values for $\Delta \mathrm{G}^{\circ}$ (temperature) are -22.66 $(298 \mathrm{~K}),-22.09(303 \mathrm{~K}),-21.81(308 \mathrm{~K}),-21.21(313 \mathrm{~K})$ and $-20.71 \mathrm{~kJ} \mathrm{~mol}^{-1}(318 \mathrm{~K}) ; \Delta \mathrm{S}^{\circ}$ is $-95.75 \mathrm{~J} \mathrm{~mol}^{-1} \mathrm{~K}^{-1}$ and $\Delta \mathrm{H}^{\circ}$ is $-51.20 \mathrm{~kJ} \mathrm{~mol}^{-1}$. Negative values of $\Delta \mathrm{G}^{\mathrm{o}}$ indicate spontaneous adsorption of $\mathrm{As}(\mathrm{V})$ by the adsorbent and the negative value of $\Delta \mathrm{S}^{\circ}$ suggests a decrease in disorder at the solid-solution interface during the adsorption of $\mathrm{As}(\mathrm{V})$ in aqueous solution by $\mathrm{Ch}-\mathrm{FeCL}$. The negative value of $\Delta \mathrm{H}$ confirms the exothermic nature of the adsorption process.

\section{Desorption of As(III) and As(V)}

Desorption studies were performed using citric acid, hydrochloric acid and tartaric acid solutions for extraction. Saturation of the adsorbent with As(III) or As(V) was initially promoted and after this procedure, the Ch-FeCL beads were placed in contact with the desorbent.

Citric acid showed the best ability for desorption compared to the other acids, presenting a removal of $36 \%$ for $\mathrm{As}(\mathrm{III})$ and $56 \%$ of $\mathrm{As}(\mathrm{V})$ at the concentration of $0.01 \mathrm{~mol} \mathrm{~L}^{-1}$. Desorption performed in cycles was carried out with the objective of obtaining greater recovery of the adsorbent. After five cycles, removals of 74 and $100 \%$ of $\mathrm{As}(\mathrm{III})$ and $\mathrm{As}(\mathrm{V})$ were obtained, respectively, for the Ch-FeCL beads. The best performance obtained with respect to desorption with citric acid is due to its ability to form complexes with $\mathrm{Fe}^{3+}$, which facilitates the removal of arsenic species $\left(\mathrm{HAsO}_{4}{ }^{2-}, \mathrm{H}_{2} \mathrm{AsO}_{4}^{-}, \mathrm{H}_{2} \mathrm{AsO}_{3}^{-}\right)$adsorbed on the $\mathrm{Fe}^{3+}$ adsorption site. ${ }^{40}$ Furthermore, the use of citric acid as an arsenic extracting solution is promising because it is a natural organic acid, non-toxic, easily degraded in the environment and low cost. ${ }^{40}$

Ch-FeCL was submitted to four adsorption/desorption cycles in order to evaluate the reuse of the adsorbent material. In this procedure, the beads saturated with arsenate ions were submitted to five desorption cycles of $12 \mathrm{~h}$ each and reused in adsorption. The procedure was repeated until completing four successive adsorption/ desorption cycles and at the end of this process there was a decrease in the adsorption capacity of Ch-FeCL by about 42 and $20 \%$ for As(III) and As(V), respectively. Thus, the adsorbent presents the ability to be reused several times without the need to exchange it for new beads.

Effect of interference of chloride, nitrate, sulfate and phosphate ions on the adsorption capacity of $\mathrm{As}(\mathrm{III})$ and As(V)

Figure 6 shows the values of As(III) and As(V) adsorption capacity in solutions containing chloride, nitrate, sulfate and phosphate ions. It is observed that the percentage of As(III) and $\mathrm{As}(\mathrm{V})$ removal decreases with increase in charge and concentration of the interfering ion. Therefore, $\mathrm{PO}_{4}{ }^{3-}$ was the anion that caused the greatest reduction in adsorption, followed by sulfate, nitrate and chloride ions which had the smallest influence on adsorption of As(III) and As(V) when compared with adsorption in the absence of the studied anions (blank). Reductions of 17 and $25 \%$ can be observed in Figure 6 for the adsorption of As(III) and As(V), respectively, when phosphate concentration is $1 \mathrm{mmol} \mathrm{L}^{-1}\left(95 \mathrm{mg} \mathrm{L}^{-1}\right)$, close to that of arsenate $\left(75 \mathrm{mg} \mathrm{L}^{-1}\right)$; and reductions were 80 and $77 \%$ for $\mathrm{As}(\mathrm{III})$ and $\mathrm{As}(\mathrm{V})$, respectively, when phosphate concentration increased to $50 \mathrm{mmol} \mathrm{L}^{-1}$ (9497 $\mathrm{mg} \mathrm{L}^{-1}$ ). Gupta et al., ${ }^{19}$ studying the effect of sulfate, phosphate and silicate anions on the adsorption of As(III) and As(V) by an chitosan-iron composite in the form of granules, also observed a greater percentage of adsorption reduction for phosphate followed by sulfate for As(III) and As(V). This interference effect is probably explained by the chemical similarity of arsenate and phosphate in aqueous solution: both ions can form very stable complexes with iron. ${ }^{18,23}$

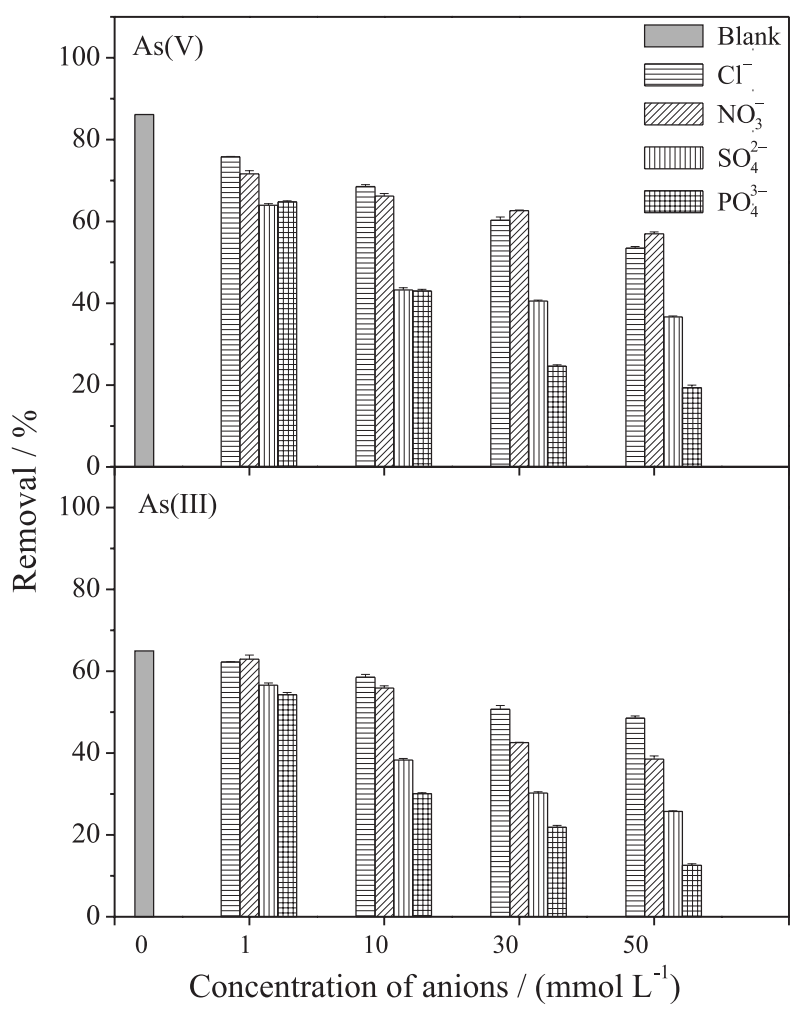

Figure 6. Effect of chloride, nitrate, sulfate and phosphate ions on adsorption of $\mathrm{As}(\mathrm{III})$ and $\mathrm{As}(\mathrm{V})$ by Ch-FeCL.

\section{Column study}

Column adsorption studies were performed to demonstrate the applicability of the Ch-FeCL adsorbent 
for removal of $\mathrm{As}(\mathrm{V})$ and $\mathrm{As}(\mathrm{III})$ from water. Figure 7 shows the breakthrough curve for a feed concentration of $0.5 \mathrm{mg} \mathrm{L}^{-1}$ at $\mathrm{pH}$ 7. It is observed that the concentrations of $\mathrm{As}(\mathrm{V})$ and $\mathrm{As}(\mathrm{III})$ could be reduced from 0.5 to $0.01 \mathrm{mg} \mathrm{L}^{-1}$ with 759 and 60 bed volumes (BV), respectively. Gupta et al. ${ }^{19}$ conducted column tests using iron-chitosan composites from real-life arsenic contaminated groundwater. Their results showed that ironchitosan flakes (ICF) could treat $147 \mathrm{BV}$ of As(III) and $112 \mathrm{BV}$ of As(V)-spiked groundwater with an As(III) or $\mathrm{As}(\mathrm{V})$ in concentration of $0.5 \mathrm{mg} \mathrm{L}^{-1}$ and $\mathrm{pH}$ adjusted to 7. Gupta and Sankararamakrishnan ${ }^{20}$ also performed column studies using iron chitosan spacer granules (ICS), which after their preparation were maintained in a saturated sucrose solution to improve porosity. Their results showed that iron chitosan spacer granules (ICS) could treat $132 \mathrm{BV}$ of As(III) and $210 \mathrm{BV}$ of $\mathrm{As}(\mathrm{V})$-spiked groundwater with an $\mathrm{As}(\mathrm{III})$ or $\mathrm{As}(\mathrm{V})$ concentration of $0.5 \mathrm{mg} \mathrm{L}^{-1}$ and $\mathrm{pH}$ adjusted to 7 . Boddu et al.,${ }^{17}$ using a chitosan-coated biosorbent $(\mathrm{CCB})$ reported that the breakthrough point was about 40 and $120 \mathrm{BV}$ for $\mathrm{As}(\mathrm{III})$ and $\mathrm{As}(\mathrm{V})$ removal in concentration of 91 and $101 \mathrm{mg} \mathrm{L}^{-1}$, respectively, in aqueous solutions adjusted to $\mathrm{pH} 4$. Gang et al. ${ }^{21}$ studied the behavior of the rupture curve for iron-impregnated chitosan granules in the adsorption of As(III) in aqueous solutions adjusted to $\mathrm{pH} 8$ with an influent concentration of $0.308 \mathrm{mg} \mathrm{L}^{-1}$. Results showed that the iron-impregnated chitosan granules can treat $768 \mathrm{BV}$ for removal of As(III). The studies presented above involving adsorption of arsenic in the column differ by the initial concentration used, $\mathrm{pH}$ and flow rate of the feed solution to the column, which results in different values for the BV. The results of BV previously encountered for $\mathrm{As}(\mathrm{V})$ were lower than those found in the present study. Gang et al. ${ }^{21}$ found a much higher BV (768) for As(III) when compared to other studies, which used a flow rate of $0.41 \mathrm{~mL} \mathrm{~min}^{-1}$ and

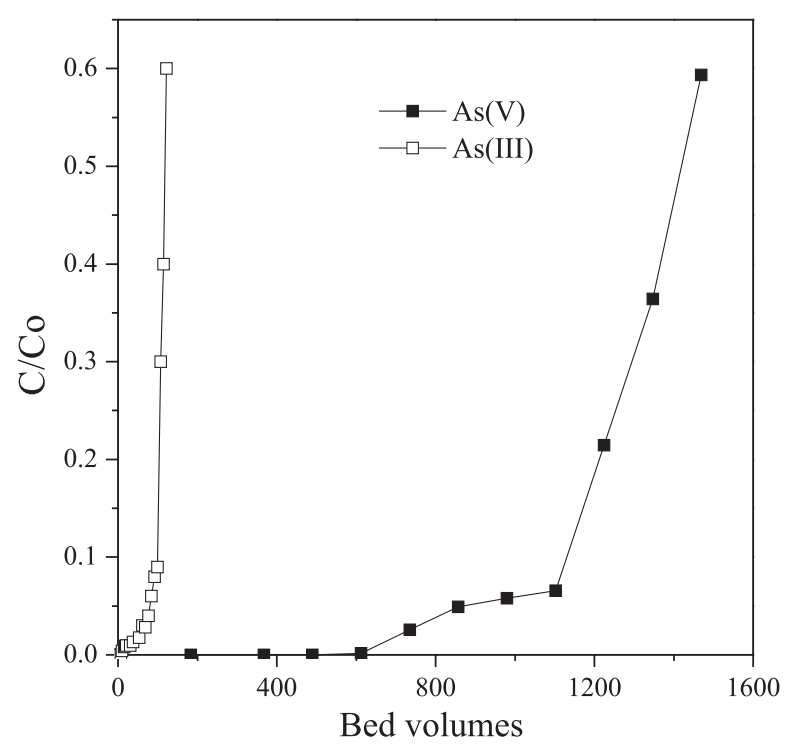

Figure 7. Breakthrough adsorption curves of As(III) and As(V) using Ch-FeCL. Conditions: initial concentration $=0.5 \mathrm{mg} \mathrm{L}^{-1} ; \mathrm{pH} 7$; flow rate $=2 \mathrm{ml} \mathrm{min}{ }^{-1}$; amount of the adsorbent: $0.25 \mathrm{~g} \mathrm{As}(\mathrm{V})$ and $1.0 \mathrm{~g} \mathrm{As}(\mathrm{III})$.

$\mathrm{pH}$ 8. In other studies, the conditions used were flow rate of $2.5 \mathrm{~mL} \mathrm{~min}^{-1}, \mathrm{pH} 7$ and flow rate of $2.0 \mathrm{ml} \mathrm{min}^{-1}$, as in the present study and two others..$^{17,19,20}$ The higher BV found (768 BV) for As(III) can be justified by the use of lower flow rates through the column which result in greater contact time of As(III) with the column bed, and $\mathrm{pH} 8$ increases the number of anionic species of As(III) which is controlled by $\mathrm{H}_{3} \mathrm{AsO}_{3} \leftrightarrows \mathrm{H}_{2} \mathrm{AsO}_{3}^{-}+\mathrm{H}^{+}(\mathrm{pKa} 9.22)$, increased the quantity adsorbed by the adsorbent.

\section{Accuracy of the analytical method}

The accuracy of the developed analytical method for determination of $\mathrm{As}(\mathrm{III})$ and $\mathrm{As}(\mathrm{V})$ was checked by addition and recovery experiment performed on mine (mine D) and river samples (Ribeirão Carmo) shown in

Table 3. Physicochemical characterization and As(III) and As(V) concentrations in water samples collected in the region of the Quadrilátero Ferrífero

\begin{tabular}{lcccccccc}
\hline Sample & $\mathrm{pH}$ & Eh / $\mathrm{mV}$ & $\begin{array}{c}\text { Temperature / } \\
{ }^{\circ} \mathrm{C}\end{array}$ & $\begin{array}{c}\text { Electrical } \\
\text { conductivity / } \\
(\mu \mathrm{S} \mathrm{cm})^{-1}\end{array}$ & $\begin{array}{c}\text { Salinity / } \\
\left(\mathrm{mg} \mathrm{L}^{-1}\right)\end{array}$ & $\begin{array}{c}\text { Dissolved } \\
\text { oxygen / } \\
\left(\mathrm{mg} \mathrm{O}_{2} \mathrm{~L}^{-1}\right)\end{array}$ & $\begin{array}{c}\mathrm{As}(\mathrm{III})^{\mathrm{a}} / \\
(\mu \mathrm{g} \mathrm{L})^{-1}\end{array}$ & $\begin{array}{c}\text { As(V) } / \\
(\mu \mathrm{g} \mathrm{L})^{-1}\end{array}$ \\
\hline Mine A & 6.4 & 153.9 & 20.1 & 22.6 & 19.0 & 14.10 & $<0.20$ & $2.58 \pm 0.71$ \\
Mine B & 6.6 & 21.8 & 19.9 & 90.0 & 78.0 & 21.48 & $31.28 \pm 0.87$ & $164.61 \pm 2.75$ \\
Mine C & 5.6 & 88.0 & 25.6 & 133.7 & 116.0 & 13.80 & $18.54 \pm 0.20$ & $120.67 \pm 1.48$ \\
Mine D & 6.9 & 90.3 & 22.3 & 180.7 & 156.0 & 14.16 & $<0.20$ & $7.90 \pm 0.12$ \\
Mine E & 6.6 & 81.2 & 19.2 & 22.7 & 20.0 & 13.26 & $1.18 \pm 0.26$ & $5.56 \pm 0.51$ \\
Mine F & 6.1 & 163.2 & 20.4 & 29.3 & 25.0 & 12.24 & $1.50 \pm 0.05$ & $12.27 \pm 0.41$ \\
Tap water & 5.8 & 131.6 & 20.3 & 84.5 & 73.0 & 14.46 & $11.04 \pm 0.34$ & $79.94 \pm 1.06$ \\
Ribeirão do Carmo & 7.2 & 16.6 & 23.5 & 135.0 & 203.0 & 15.24 & $4.40 \pm 0.03$ & $22.86 \pm 0.14$ \\
\hline
\end{tabular}

Eh: reduction potential. 
Table 3. The two water samples were spiked with 1, 3 and $10 \mu \mathrm{g} \mathrm{L}^{-1}$ of the $1 \mathrm{mg} \mathrm{L}^{-1}$ stock solutions of As(III) and As(V). For each spiked level, three quantification tests were performed. Recoveries obtained from the sample of mine water fortified at 1,3 and $10 \mu \mathrm{g} \mathrm{L}^{-1}$ were 97.2, 96.3 and $102.1 \%$ for As(III), and 96.4, 103.4 and $99.7 \%$ for As(V). Recoveries obtained from the sample of river water spiked with 1, 3 and $10 \mu \mathrm{g} \mathrm{L}^{-1}$ were 98.5, 102.8 and 97.8 for As(III), and 98.4, 102.1 and 103.4 for $\mathrm{As}(\mathrm{V})$. Therefore, the determination of $\mathrm{As}(\mathrm{III})$ and $\mathrm{As}(\mathrm{V})$ in natural waters showed good agreement with additionrecovery experiments.

Analyses of As(III) and As(V) in natural water samples were performed using two calibration curves in the range 1 to $10 \mu \mathrm{g} \mathrm{L}^{-1}$, one for As(III) and the other for As(V). The calibration curves presented straight line equations of

$\mathrm{A}=0.0299[\mathrm{As}(\mathrm{III})]+0.0092\left(\mathrm{R}^{2}=0.9991\right)$ and

$\mathrm{A}=0.0434[\mathrm{As}(\mathrm{V})]+0.0107\left(\mathrm{R}^{2}=0.9997\right)$.

The limits of detection $(3 \sigma)$ and of quantification $(10 \sigma)$ were calculated as 0.20 and $0.43 \mu \mathrm{g} \mathrm{L}^{-1}$ for As(III), and 0.54 and $0.89 \mu \mathrm{g} \mathrm{L}^{-1}$ for As(V), respectively. Precision was expressed in terms of repeatability, based on calculation of the estimate of the relative standard deviation (RSD). Samples of river (Carmo River) and mine water (mine D) were spiked with 1, 3 and $10 \mu \mathrm{g} \mathrm{L} \mathrm{L}^{-1}$ of As(III) and As(V) $(n=3)$, in which the obtained RSD was less than $8 \%$ for the different arsenic concentrations.

Applicability of the adsorbent to water naturally contaminated with arsenic

To verify the influence of the natural water matrix, dry Ch-FeCL beads were applied to water samples naturally contaminated with As and collected from various groundwater and surface water sources located in the region of the Quadrilátero Ferrífero. Eight sampling points were used, consisting of six from mines, one tap water sample and one sample from the Carmo River (Table 3). The water samples were collected and physico-chemically characterized by in situ analyses for $\mathrm{pH}, \mathrm{E}_{\mathrm{h}}$, temperature, electrical conductivity, salinity and dissolved oxygen, according to the procedure described by Mendes et al. ${ }^{27}$ To the water samples, $1 \mathrm{mg} \mathrm{L}^{-1}$ of As(III) and As(V) was added. This addition was necessary to evaluate the efficiency of the adsorption process for removal of As(III) and As(V) in natural matrices, and in regions of the Quadrilátero Ferrífero, groundwater concentrations exceeding $1 \mathrm{mg} \mathrm{L}^{-1}$ were already observed. ${ }^{25}$ Natural waters after treatment presented arsenic concentrations below the maximum allowed by Brazilian legislation $\left(10 \mu \mathrm{g} \mathrm{L}^{-1}\right)$, making them appropriate for human consumption.

\section{Conclusions}

The crosslinked chitosan-Fe(III) adsorbent (Ch-FeCL) was prepared in the form of beads, which after drying presented an average diameter of $1 \mathrm{~mm}$ and were stable in air. The dry Ch-FeCL beads was initially evaluated in the adsorption/desorption of $\mathrm{As}(\mathrm{III})$ and $\mathrm{As}(\mathrm{V})$ from aqueous solutions at $\mathrm{pH}$ 7.0. Equilibrium adsorption values fit well to the Langmuir and Freundlich models. The maximum adsorption capacities of Ch-FeCL estimated by the Langmuir adsorption model at $25{ }^{\circ} \mathrm{C}$ were 21.24 and $27.59 \mathrm{mg} \mathrm{g}^{-1}$ for $\mathrm{As}(\mathrm{III})$ and $\mathrm{As}(\mathrm{V})$, respectively.

Column studies presented promising results, mainly because of their applicability at neutral $\mathrm{pH}$ for removal of $\mathrm{As}(\mathrm{III})$ and $\mathrm{As}(\mathrm{V})$ which makes the Ch-FeCL beads attractive for development of filters for use in water treatment in areas with arsenic contamination.

The results were also satisfactory when employing dry Ch-FeCL beads for the removal of As(III) and As(V) from samples of mine water, tap water and river water collected in the region of the Quadrilátero Ferrífero, Minas Gerais State, Brazil. Based on these results, it is suggested that dry Ch-FeCL beads have the potential to be an efficient adsorbent for removal of $\mathrm{As}(\mathrm{III})$ and $\mathrm{As}(\mathrm{V})$ from water samples in contaminated regions.

\section{Acknowledgements}

The authors acknowledge the financial support of the Fundação de Amparo à Pesquisa do Estado de Minas Gerais (FAPEMIG) and the Conselho Nacional de Desenvolvimento Científico e Tecnológico (CNPq).

\section{References}

1. Shevade, S.; Ford, R. G.; Water Res. 2004, 38, 3197.

2. Genç-Fuhrman, H.; Bregnhoj, H. D.; McConchie, D.; Water Res. 2005, 39, 2944.

3. Ko, I.; Kim, J.-Y.; Kim, K.-W.; Colloids and Surfaces, A 2004, $234,43$.

4. Ghimire, K. N.; Inoue, K.; Yamaguchi, H.; Makino, K.; Miyajima, T.; Water Res. 2003, 37, 4945.

5. Mondal, P.; Majunder, C. B.; Mohant, B.; J. Hazard. Mater. 2006, 137, 464.

6. Tapio, S.; Groshe, B.; Mutation Research. 2006, 612, 215.

7. World Health Organization (WHO); Guidelines for DrinkingWater Quality, vol. 1, $2^{\text {nd }}$ ed.; Genève, Swiss, 1993. 
8. Brazilian Ministry of Health; Establishes Procedures and Responsibilities Relating to Control and Surveillance of Water Quality for Human Consumption and Pattern of Drinking and other Matters, Decree No. 518 of March 25, 2004, Repealing Ordinance No. 1469 of December 29, 2000.

9. Mohan, D.; Pittman Jr., C. U.; J. Hazard. Mater. 2007, 142, 1.

10. United States Environmental Protection Agency (US EPA); Technologies and Costs for Removal of Arsenic from Drinking Water, US EPA, Office of Water: Washington, DC, USA, 2000.

11. Machado, N. R. C. F.; Bigatão, D. M. M. M.; Quím. Nova 2007, 30,1108 .

12. Lin, T.-F.; Wu, J.-K.; Water Res. 2001, 35, 2049.

13. Yang, L.; Shahrivari, Z.; Liu, P. K. T.; Sahimi, M.; Tsotsis, T. T.; Ind. Eng. Chem. Res. 2005, 44, 6804.

14. Kartal, S. N.; Imamura, Y.; Bioresource Technol. 2005, 96, 389.

15. Dambies, L.; Vicent, T.; Guibal, E.; Water Res. 2002, 36, 3699.

16. Chen, C.-Y.; Chang, T.-H.; Kuo, J.-T.; Chen, Y. F.; Chung, Y.-C.; Bioresource Technol. 2008, 99, 7487.

17. Boddu, V. M.; Abburi, K.; Talbott, J. L.; Smith, E. D.; Haasch, R.; Water Res. 2008, 42, 633.

18. Fagundes, T.; Bachmann, A. W. L.; Tomaz, H. S. O.; Rodrigues, C. A.; Quím. Nova 2008, 31, 1305.

19. Gupta, A.; Chauhan, V. S.; Sankararamakrishnan, N.; Water Res. 2009, 43, 3862.

20. Gupta, A.; Sankararamakrishnan, N.; Bioresource Technol. 2010, 101, 2173.

21. Gang, D. D.; Deng, B.; Lin, L.; J. Hazard. Mater. 2010, 182, 156.

22. Santos, H. H.; Demarchi, C. A.; Rodrigues, C. A.; Nedelko, J. M. G. N.; Waniewska, A. S.; Chemosphere 2011, 82, 278.

23. Bradruzzaman, M.; Westerhoff, P.; Knappe, D. R. U.; Water Res. 2004, 38, 4002.

24. Toledo, T. V.; Bellato, C. R.; Rosário, R. H.; Marques Neto, J. de O.; Quím. Nova 2011, 34, 561.
25. Deschamps, E.; Cimineli, V. S. T.; Lange, F. T.; Matschullat, J.; Raue, B.; Schimidt, H.; J. Soil Sediments 2002, 2, 216.

26. Ngah, W. S. W.; Ghani, S. A.; Kamari, A.; Bioresource Technol. 2005, 96, 443.

27. Mendes, G.; Bellato, C. R.; Marques Neto, J. O.; Quím. Nova 2009, 32, 1471.

28. Zhang, Y.; Xue, C.; Xue, Y.; Gao, R.; Zhang, X.; Carbohydr. Res. 2005, 340, 1914.

29. Webster, A.; Halling, M. D.; Grant, D. M.; Carbohydr. Res. 2007, 342, 1189

30. Wang, S.-G.; Sun, X.-F.; Liu, X.-W.; Gong, W.-X.; Gao, B.-Y.; Bao, N.; Chem. Eng. J. 2008, 142, 239.

31. Reed, B. E.; Vaughan, R.; Jiang, L.; J. Environ. Eng. 2000, 126, 869.

32. Udayabhaskar, P.; Iyengar, L.; Rao, A. V. S. P.; J. Appl. Polym. Sci. 1990, 39, 739 .

33. Katsoyiannis, I. A.; Zouboulis, A. I.; Water Res. 2002, 36, 5141.

34. Zhang, Y.; Yang, M.; Huang, X.; Chemosphere 2003, 51, 945.

35. Ho, Y. S.; Mckay, G.; Process Biochem. 1999, 34, 451.

36. Bhattacharyya, K. G.; Sharma, A.; Dyes and Pigm. 2005, 65, 51.

37. Vitali, L.; Laranjeira, M. C. M.; Fávere, V. T.; Gonçalves, N. S.; Quím. Nova 2008, 31, 1400.

38. Dizge, N.; Aydiner, C.; Demirbas, E.; Kobya, M.; Kara, S.; J. Hazard. Mater. 2008, 150, 737.

39. Allen, S. J.; Mckay, G.; Khader, K. Y. H.; Environ. Pollut. 1989, $56,39$.

40. Silva, A. M. N.; Kong, X.; Parkin, M. C.; Cammack, R.; Hider, R. C.; Dalton Trans. 2009, 40, 8616.

Submitted: August 14, 2012 Published online: February 18, 2013 